ISSN: 2386-3919 - e-ISSN: 2386-3927

DOI: https://doi.org/10.14201/et20203814968

\title{
CLIL TEACHER TRAINING: LACKS AND SUGGESTIONS FROM A SYSTEMATIC LITERATURE REVIEW
}

\author{
Formación del profesorado AICLE: carencias y sugerencias \\ a partir de una revisión sistemática de literatura
}

Maria Elisabetta PORCEDDA y Juan GONZÁLEZ-MARTíneZ

Recibido: 22/04/2020; Aceptado: 14/07/2020; Publicado: 30/12/2020

Ref. Bibl. MARIA ELISABETTA PORCEDDA y JUAN GONZÁLEZ-MARTÍNEZ. CLIL Teacher Training: Lacks and Suggestions from a Systematic Literature Review. Enseñanza E Teaching, 38, 1-2020, 49-68.

SUMMARY: This systematic literature review aims firstly at highlighting lacks and suggestions and/or good practices in CLIL teacher training, analysing and crossing the results, obtained from academic repositories; then at contributing to reach an optimal level of training for CLIL teachers, highlighting good practices as suggestions to fill the lacks.

The 39 documents, which describe studies and mostly practices from almost all the European countries, have been obtained by Scopus, Educational Resources Information Centre (ERIC), ScienceDirect and partially Google Scholar, through the descriptor "CLIL teacher training" and a post-reading selection of the articles. Their qualitative data provided an exhaustive picture of the comprehensiveness of results, required by the method of systematic reviews.

CLIL results to be a complex approach, involving many aspects which need to be considered. It is primarily perceived to be as engaging for students as demanding for teachers, due to its being learner-centred, with a large use of ICTs and online tools, as its implementation through a new pedagogy and modern teaching strategies, such as flipped-classroom and task-based. This is the theoretical starting point of the different actions and policies set up in the countries to train teachers for CLIL. But the results of this review, which draw the characteristics to take into account to train future CLIL teachers, underline the need of pre-service teacher training at University, hitherto generally disregarded in favour of in-service preparation. Concerning this latter, from 
the stakeholders in particular it is suggested continued update in CLIL method and research; further collaboration with colleagues, especially telecollaboration, which can be the answer to the need of CLIL update and to share good practices in authentic online communities; last but not least, further pedagogical preparation and management of ICTs, because CLIL aims to change the traditional schooling.

Key words: CLIL; teacher training; good practices; educational improvement; collaborative update.

RESUMEN: Esta revisión sistemática de la literatura tiene como primer objetivo destacar las carencias y sugerencias y/o buenas prácticas en la formación de docentes AICLE (aprendizaje integrado de contenidos y lenguas extranjeras), a fin de contribuir al diseño de una formación específica óptima para los profesores de AICLE. Se ha llevado a cabo por medio del análisis de 39 documentos analizados, que presentan investigaciones y prácticas provenientes de casi todos los países europeos, y que han sido obtenidos en Scopus, Educational Resources Information Centre (ERIC), ScienceDirect y en parte Google Scholar, por medio de búsquedas iniciales con el descriptor «CLIL teacher training" $\mathrm{y}$ un proceso de selección posterior.

El AICLE es un enfoque complejo que involucra muchos aspectos que deben considerarse. Resulta tan atractivo para los estudiantes como exigente para los profesores, pues se centra en el alumno, con un gran uso de las Tic y de las herramientas en línea, y también por su implementación a través de una nueva pedagogía y asociado a unas estrategias de enseñanza innovadoras. Este es el punto de partida teórico de las diferentes acciones y políticas establecidas en los países para capacitar a docentes para AICLE.

Sin embargo, los resultados, que orientan la capacitación de los futuros profesores de AICLE, subrayan la necesidad de formación inicial docente específica previa al ejercicio profesional, hasta ahora generalmente ignorada a favor de la formación permanente. Con respecto a esto último, de los interesados se sugiere una actualización continua en el método AICLE y en la investigación universitaria; mayor colaboración con colegas, especialmente la telecolaboración, que puede ser la respuesta a la necesidad de actualizar AICLE y compartir buenas prácticas; por último, pero no menos importante, una mayor preparación pedagógica y gestión de las Tic, porque AICLE tiene como objetivo la innovación educativa en la escuela.

Palabras clave: AICLE; formación docente; buenas prácticas; mejora educativa; actualización colaborativa.

\section{INTRODUCTION}

\subsection{What is CLIL?}

CLIL was born in 1994 from cooperation between the Finnish University of Jyväskylä and the European Platform for Dutch education and it is so far highly recommended in the European context to achieve citizens' multilingualism. David 
MARIA ELISABETTA PORCEDDA Y JUAN GONZÁLEZ-MARTÍNEZ

Marsh, who firstly conceived CLIL, gave this definition of it: "CLIL refers to situations where subjects, or parts of subjects, are taught through a foreign language with dual-focussed aims, namely the learning of content, and the simultaneous learning of a foreign language» (in Biçaku, 2011: 3822). This is why European countries suggest, or make compulsory, that non-linguistic subject teachers, alone or in teams, have to implement CLIL for different ages or schools, after linguistic and methodologic preparation. This training concerns so many aspects, being the same CLIL definition rather generic and considered an 'umbrella' term (van Kampen, Admiraal and Berry, 2016: 1), that the opportunities of both training and implementation are various, because of its ductility. And this variety might be a concrete way for teachers to change the mainstream schooling and the evaluation of students, according to their necessary skills for their life, such as learning to learn, critical thinking, collaboration, linguistic and digital competences, and creativity.

\subsection{Theoretical starting points for teachers training}

Becoming a CLIL teacher, hence having the awareness that «CLIL teaching is not the sum of the characteristics of subject teaching and foreign language teaching put together» (Coonan, 2011: 4), has always been a difficult path, depending on its intrinsic nature of both language and content teaching and evaluation. Traditionally, "teaching is typically organised using the "one teacher one language" or "one subject one language" approach", whilst the linguistic awareness into transversal and inclusive curricula can "provide more authentic learning geared towards reallife situations» (European Commission Note, 2019: 24).

That is why an exhaustive pre-service training for teachers might be not enough without thinking of a long-life in-service one, because real-life situations constantly change over time, as well as the needs of students and classrooms (Dalton-Puffer, 2011). Consequently, though CLIL is mainly a tool to achieve multilingualism at all ages, teacher training should also consider how their students learn and be able to understand how to guide them step-by-step along their own path. Besides, it also has to take into account the importance today of the Information and Communication Technology (ICT), so the adoption of the transmedia literacy, as the closer-to-student way to foster the participatory culture (González-Martínez, Serrat-Sellabona, Estebanell-Minguell, Rostan-Sánchez, and Esteban-Guitart, 2018).

Furthermore, a lack in interaction between researchers and teachers, or teachers' activities and European organization initiatives, is sometimes perceived (Czura and Papaja, 2013), whereas their cooperation might be the key for widespread CLIL implementation. 


\subsection{From theory to practice: the frameworks for CLIL}

How putting CliL into practice and dealing with practical issues, such as the best starting age or the variables in embedding content and language and many others (e.g., Czura and Papaja, 2013), has been the object of many research studies, mainly linguistically aimed and especially from the departments of English Language and Linguistics at European universities. Some of their well-known results are frameworks, which are the roots of the European teachers training content:

- The4C'sbyCoyle(1999), thefirstandmostwidespreadmodelforteachers, inorder to plan bearing in mind the fields of Content-Cognition-Communication-Culture.

- The clil Pyramid, «a flexible planning tool that enables teachers to develop innovative materials based on the 4Cs-Framework" (Meyer, 2010: 11).

- The three-dimensional model (Ball, Kelly and Klegg, 2015) and its various interactions among Concept-Procedure-Language, which aims to ease planning for teachers.

- The Language Triptych (Coyle, Hood, and Marsh, 2010), sometimes named "3 A's tool» (Analyse, Add, Apply), whose adoption aims to underline different but interconnected language functions within the CLIL implementation (of, for, through learning).

All the above frameworks concern CLIL lesson planning. Furthermore, other research has suggested models for student evaluation, but relevant for planning tasks too, as the Mapping Pluriliteracies Development visual, elaborated by the Graz Group within a project of the European Centre for Modern Languages (ECML). It aims to map the learner progressions in knowledge construction and meaning-making, other than in the foreign language, in the cuIl context (Meyer, Coyle, Halbach, Schuck and Ting, 2015). Also deserving to be cited here the LOCIT (Lesson Observation Critical Incident Technique), by Aberdeen University (Coyle, 2013), whose process, although not specifically born for CuIL lessons, is quite often applied to them, in order to share successful learning processes in the classroom between teachers and students, after the teachers' evaluation of the strengths and weaknesses of the lessons.

Finally, in 2014 the "European Framework for ClIL Teachers Education» has been published online as the result of a project of the European Centre for Modern Languages of the Council of Europe (ECML) (Marsh, Mehisto, Wolff and FrígolsMartín, 2012). It "aims to provide a set of principles and ideas for designing CLIL professional development curricula" and "as a tool for reflection", so as a "model", not as "a prescriptive template», recognising significant differences about the CLIL implementation in the Council of Europe member states (p. 3). It firstly gives a picture of the target professional competences of a CLIL teacher and, on this basis, builds three modules for the teacher professional development (Approaching/ Implementing/Consolidating CLIL). It is to highlight that it was written after a European consultation and «an examination of teacher education learning and curricular needs in ClIL contexts» (p. 3). 
All these efforts are derived from the fact that CLIL implementation is highly recommended by the European Union (e.g., European Council, 2008; European Commission SWD, 2018), because of its contribution to foster multilingualism for the European citizens. With this aim, CLIL involves non-linguistic subject teachers, to widen the opportunities of FL adoption. They, on the one hand, are often enthusiastic about this relatively new approach (Cinganotto, 2016), whilst on the other there is a large part of them who does not quite feel up to the task (Pérez Cañado, 2016b), due to its complexity, which makes their initial training not exhaustive and with lacks to be filled.

\section{RESEARCH QUESTIONS}

Conscious that "there is a well-documented paucity of researches into the needs of teacher training for CLIL" (Pérez Cañado, 2016a: 6), this paper aims to check if primarily the CLIL stakeholders, as the researchers, in the literature underline lacks within CLIL training, as well as suggestions and relevant practices, related to the lacks, so as to evaluate pros and cons in the present teachers' training implementation for future improvement of this approach.

In particular, we are going to answer to the questions underneath:

- How and in what fields are teachers trained so as to implement CLIL?

- What lacks in CLIL training do teachers and/or researchers perceive before, during and after their implementation?

- Have they any suggestions to improve CLIL training?

\section{METHODOLOGY}

Following Okoli and Schabram (2010), it has been chosen to carry out a systematic literature review as «a systematic, explicit, and reproducible method for identifying, evaluating, and synthesizing the existing body of completed and recorded work produced by researchers, scholars, and practitioners» (p. 4).

In order to collect the qualitative data for this research, on May 29th 2019 the key words 'CLIL teacher training' were entered into three academic repositories, relevant for their results: Scopus (Elsevier), Educational Resources Information Centre (ERIC) and ScienceDirect (Elsevier). Google Scholar was added as a broader-glimpse database, but with occurrences limited to the key words in the title, because the full results were more than 11.400 . They each produced the number of references below:

- Scopus: 64

- ERIC: 44

- ScienceDirect: 119

- Google Scholar: 57 
After excluding book reviews, indices, summaries, books and conference proceedings, the selection of academic articles has been done by analysing the abstracts through the parameters: English or Spanish language, experience-based articles, centred on teacher training, including reports, proposals, qualitative and/ or quantitative analysis; European data collecting. The latter allowed us to include two reports from books about Slovakia and Hungary, countries otherwise not represented.

The final results have been so obtained by the repositories:

TABLE 1

References per repository $(\mathrm{pr}=$ peer reviewed $)$

\begin{tabular}{|c|c|c|c|}
\hline SCOPUS & ERIC & SCIENCEDIRECT & $\begin{array}{c}\text { GOOGLE } \\
\text { SCHOLAR }\end{array}$ \\
\hline $\begin{array}{c}14 / 64 ; 2 \text { also } \\
\text { in ERIC; all PR }\end{array}$ & $\begin{array}{c}17 / 44 ; 2 \text { also in Scopus and } 1 \\
\text { in Google Scholar; } 1 \text { not PR }\end{array}$ & $4 / 119$ & $\begin{array}{c}7 / 57 ; 1 \text { also in } \\
\text { ERIC; } 6 \text { not PR }\end{array}$ \\
\hline
\end{tabular}

Double references removed, the final 39 articles are primarily peer reviewed (only 6 are not, but are included for their experiential relevance) and focus on all different fields (Preschool, Primary, Secondary, University) and areas (Pre-service, In-service teachers; students) of the teacher training.

With regard to the location, nearly the entire Europe is hereby represented, although Spain holds by now "the greatest number of investigations into the topic under scrutiny» (Pérez Cañado, 2016a: 3), as it appears from the majority of our results.

They have been so scheduled: 
TABLE 2

Data sheet of the selected papers

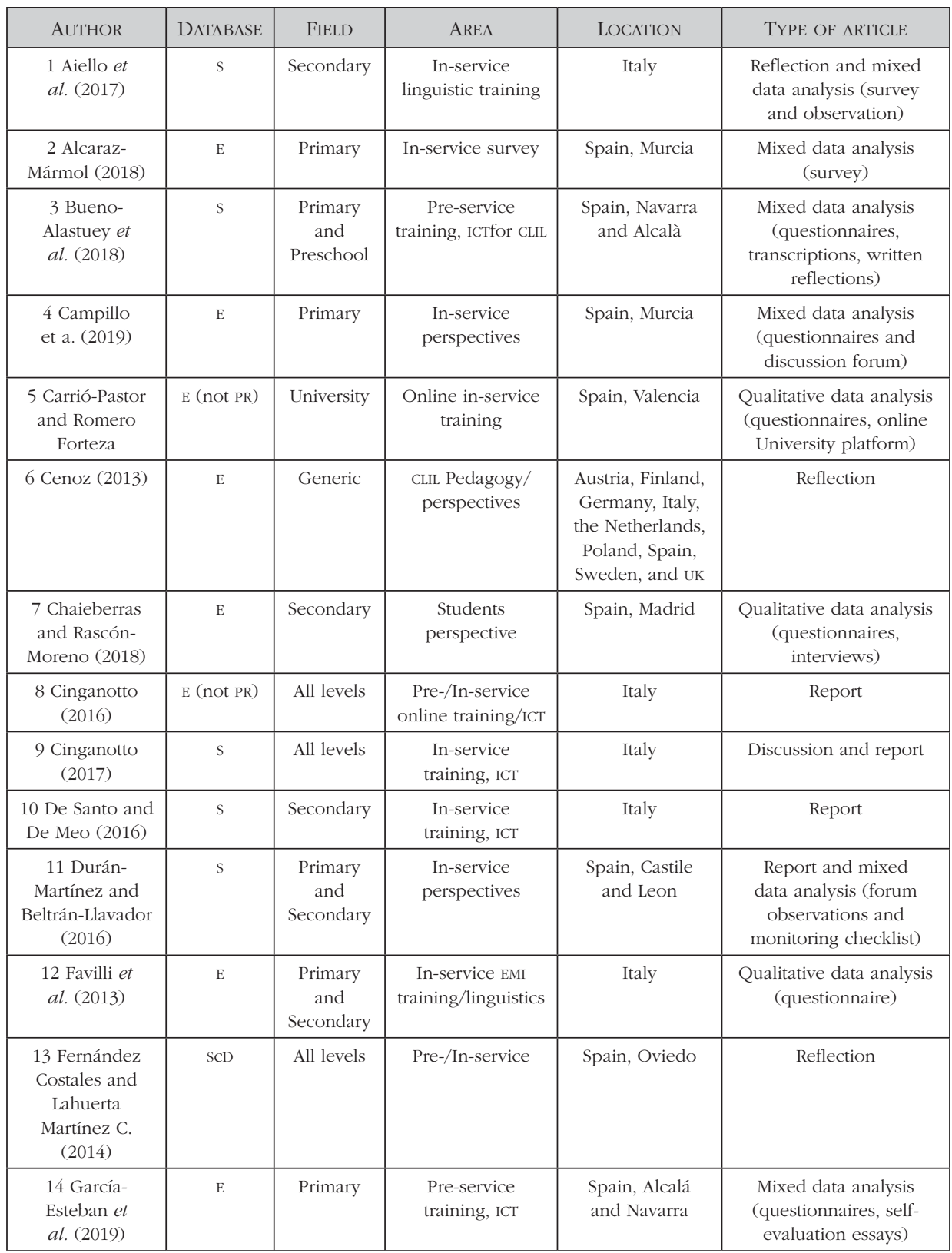


MARIA ELISABETTA PORCEDDA Y JUAN GONZÁLEZ-MARTÍNEZ CLIL TEACHER TRAINING: LACKS AND SUGGESTIONS FROM A SYSTEMATIC LITERATURE REVIEW

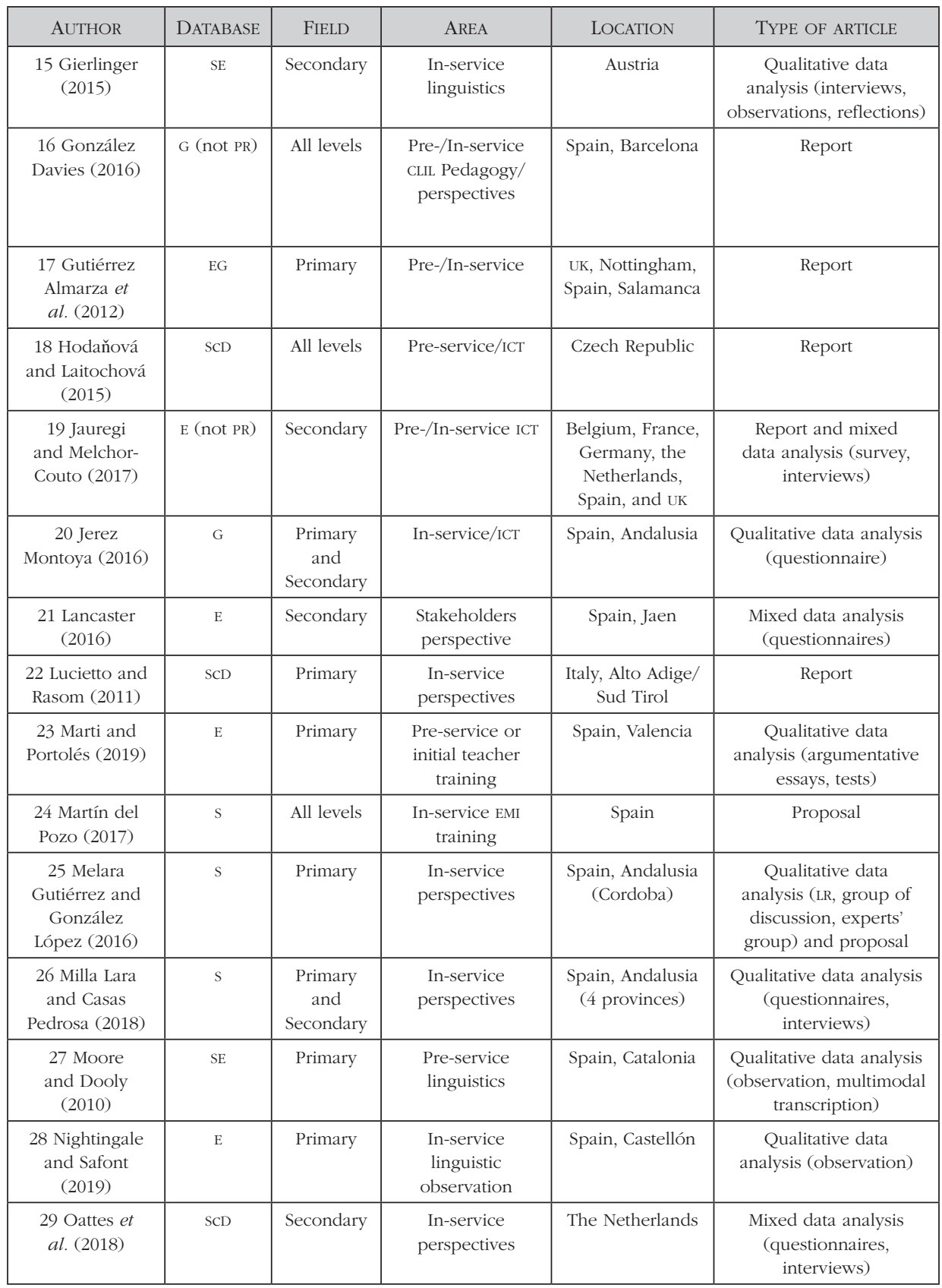


MARIA ELISABETTA PORCEDDA Y JUAN GONZÁLEZ-MARTÍNEZ

CLIL TEACHER TRAINING: LACKS AND SUGGESTIONS FROM A SYSTEMATIC LITERATURE REVIEW

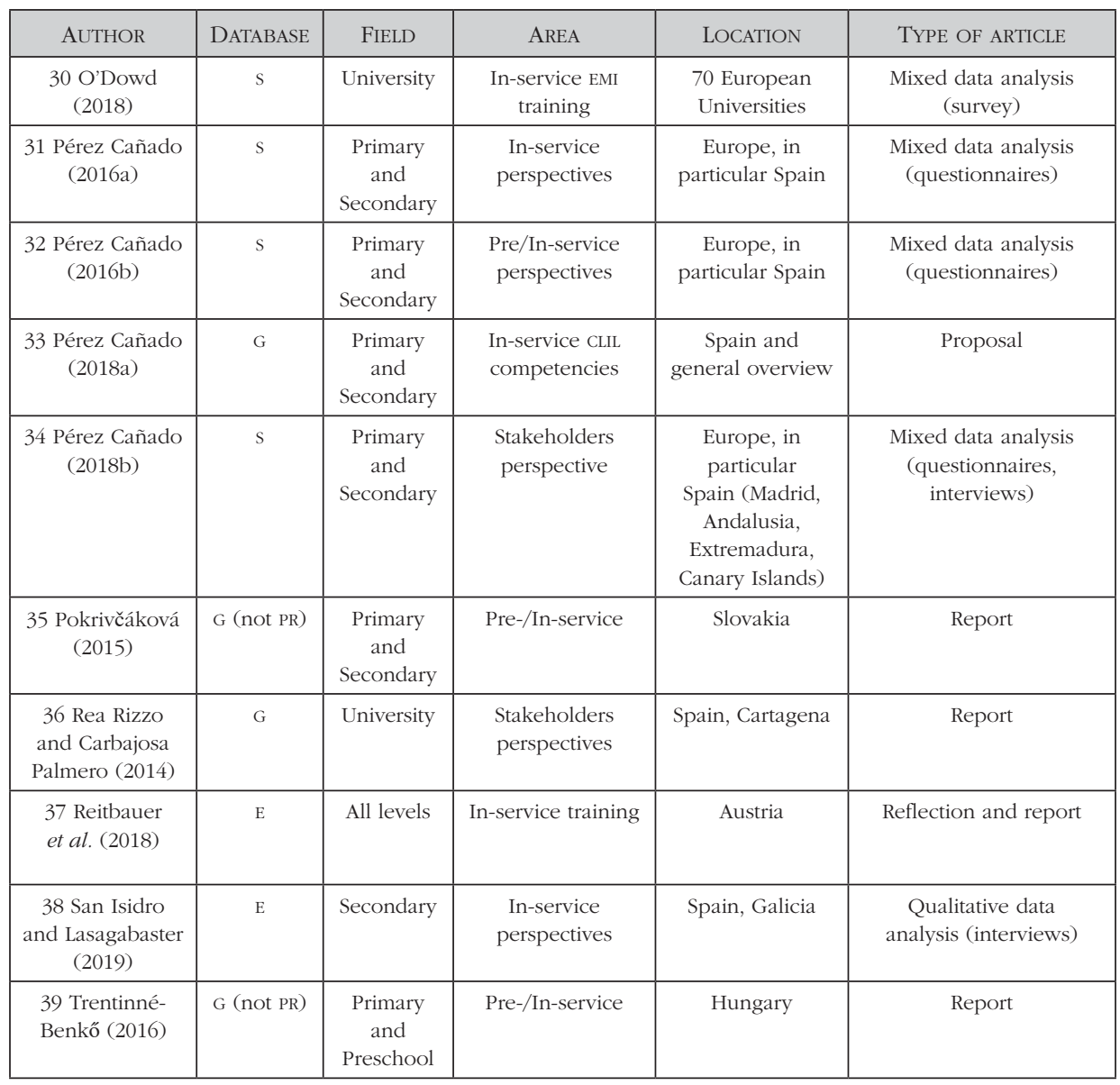

Legenda: $\mathrm{E}=$ Eric, $\mathrm{G}=$ Google Scholar, $\mathrm{S}=$ Scopus, $\mathrm{ScD}=$ ScienceDirect, $\mathrm{PR}=$ Peer Reviewed, $\mathrm{EMI}=$ EnglishMedium Instruction, LR = Literature Review.

From the analysis of the data and in order to code them through a Word textgrid, eleven macro-concepts in CLIL teacher training emerged as lacks and sixteen as related needs and/or good practices, which are reported as results of this paper (4.2 and 4.3). Finally, the coded results have been crossed and analysed to obtain relationships among lacks and suggestions (emerged also as good practices), the fields and the areas. 


\section{RESULTS}

The first consideration is that the location is not relevant, apart from the aforementioned importance of the CLIL research in Spain. Indeed, fields of training, lacks and suggestions are similar whenever clil is trained and implemented, thanks to the concerning European top-down policy since its adoption. This is an important point, because the resulting data might be assumed whenever valid.

\subsection{Fields and paths in teachers' training}

The answer to how teacher training is implemented implies the way through which it was done; hence, whether in their attendance (and at what site) or online (and from who or what institution).

The results from 30 of the collected articles ( 9 of them do not specify the location) show that this training is almost completely set at University (approximately $65 \%$ ), due to its prerogative to certify teachers' acquisition of cLIL and where the main fields of teacher training concern: FLS (88 \%), in particular English and rarely minority languages; CLIL methodology (80\%), referring to its multiple-focus approach and the scaffolding role of teachers; Linguistics (60\%); CuIL fundamentals (56\%), namely its history, definitions and diverse opportunities to be implemented (as hard or soft, content or language centred, etc.); strategies for CLIL (52\%), like task-based and input approach, flipped classroom, cooperative learning; ICTs and online tools (40\%); Pedagogy for CLIL (32\%), as socio-constructivism or bilingual Education; evaluation (20\%); and materials' development (16\%).

For the most part, there are only in-presence training and updating, or specialisation courses, for in-service teachers ( $52 \%$ ), $32 \%$ for both pre- and in-service, and rarely only for pre-service (16\%), through specific Degree or Master programs (almost all in Spain). Trainers can be lecturers or clIL experts, often from British Council, with English considered as a lingua franca, therefore the most taught. Universities also provide a few online cLIL courses, offering telecollaboration and blended modality, other than training materials, tools, networks for collaborative learning and sharing of practices. Sometimes they have successfully collaborated with other institutions, such as Official School of Languages and the Educational Departments (Spain), Teachers' Associations, and KIE (Hungary). Other institutions, whether collaborating or not with Universities, like INDIRE (Italy), eTwinning, EVO (Electronic Village Online), TESOL International Association, the Trinity College and Cambridge, have supported primarily the FL language acquisition for CLIL teachers and also the widespread diffusion and sharing of good practices, materials and tools.

\subsection{Lacks}

With regard to the second question of this paper, teachers and researchers highlight the following lacks: 
I. Foreign language (FL) competence

II. Instructional/planning problems

III. Prior CLIL training, experience or knowledge

IV. Availability/management of ICTs

V. Knowledge in language acquisition

VI. Motivation

VII. Teachers' lack of time

VIII. CLIL specific materials

IX. Support/cooperation from educational authorities or among colleagues

$\mathrm{X}$. Pedagogical/educational preparation, as in integration

XI. Language awareness

The number has not been assigned to lacks by order of importance, but simply as gradually emerging from the analysis of the documents.

The labels we attributed to each lack, as macro-concepts including different aspects, are according to what the authors conceptually highlight, often using precisely our same definition. Hence, we put, for instance, under FL competence (lack I), diverse aspects, like fluency and lack of lexical resources. But the resulting more various lacks within the references are: IX, due to the fact that it is marked the aspect of collaboration both at school and between schools and educational authorities, which foster the former; and $\mathrm{x}$, because pedagogical preparation involves many aspects, such as evidence-based research, educational strategies, consideration to students' cognitive and intercultural development and many others.

The graphic below shows the references of each lack, so as to determine their perceived order of importance:

GRAPHIC 1

References per lack

Lacks

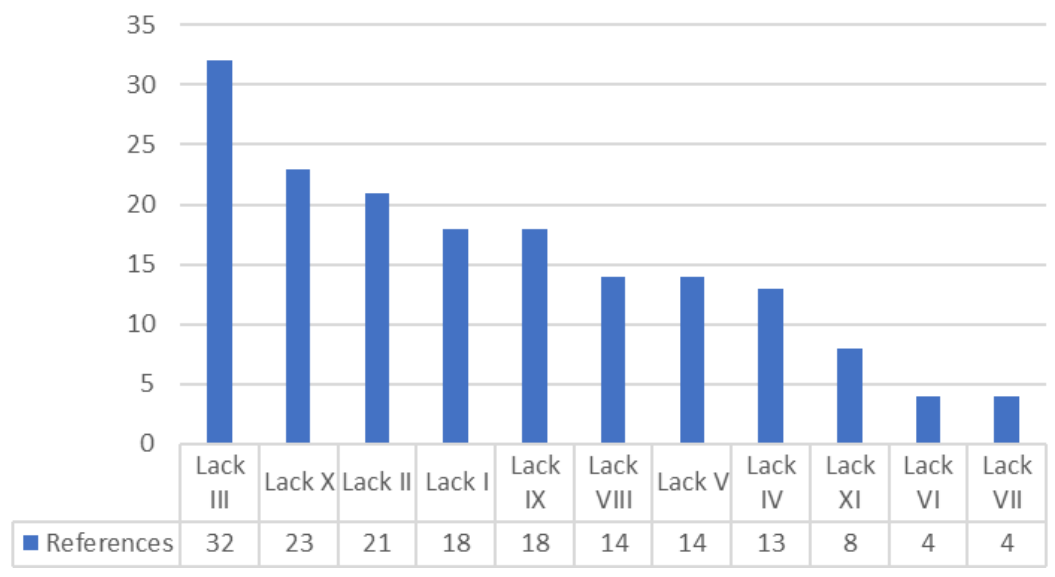


If only pre-service is considered (bearing in mind that only four papers exclusively address it), there are mentioned lacks I, II, IV, V and X, with a particular attention to II and x, which marks the need of learner-centred and collaborative methodologies acquisition.

\subsection{Suggestions and good practices}

In this section, there are listed suggestions and good practices highlighted by the authors. Within parenthesis, we show first their whole number of occurrences, namely the sum of any occurrence reported by the authors as suggestions/good practices; whilst the second number is the sum of suggestions/good practices only given as answers to precise lacks:

a. Foreign language courses/updating (26/25)

b. Language acquisition strategies (codeswitching; negotiation of codes, genres, discourse, etc.; translanguaging) (34/31)

c. CLIL methodological training/courses/experts (69/67)

d. Pedagogical-Educational updating/training (64/61)

e. Inclusion of ICTs and online tools (48/43)

f. Sharing practices and knowledge (29/26)

g. Language awareness focus $(22 / 21)$

h. Collaborative learning/practices (50/45)

i. Learning to Learn and Life-long learning (14/11)

j. Mobility exchanges (6/6)

k. Cooperation with authorities/University (26/26)

1. Multimodal/cross-curricular teaching (20/18)

m. Different students' evaluation than the mainstream (14/13)

n. Training in planning/building specific materials $(24 / 23)$

o. FL lecturers support $(5 / 4)$

p. Experiential learning $(8 / 6)$

It is here valid the same clarification on our labels and order in the list, reported above about lacks (4.2).

They refer to each lack as in the table below: 
MARIA ELISABETTA PORCEDDA Y JUAN GONZÁLEZ-MARTÍNEZ

TABLE 3

Relations between lacks and suggestions/good practices in terms of occurrences (stressed in black highest values over 10, in grey highest under 10)

\begin{tabular}{|c|c|c|c|c|c|c|c|c|c|c|c|c|c|c|c|c|}
\hline & 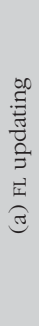 & 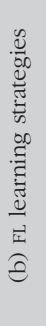 & 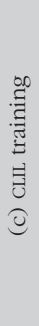 & 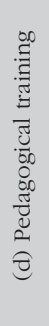 & 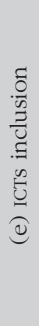 & 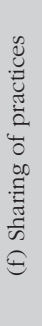 & 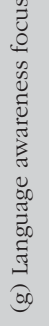 & 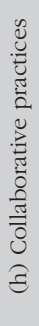 & 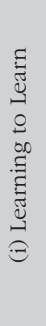 & 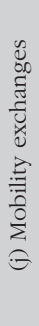 & 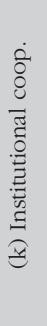 & 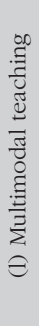 & 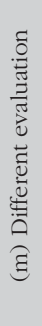 & 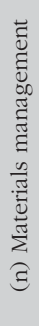 & 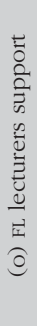 & 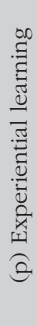 \\
\hline $\begin{array}{l}\text { (I) Foreign } \\
\text { language } \\
\text { competence }\end{array}$ & 13 & 8 & 9 & 2 & 0 & 0 & 5 & 1 & 1 & 3 & 4 & 0 & 0 & 0 & 1 & 0 \\
\hline $\begin{array}{l}\text { (II) Instructional } \\
\text { problems }\end{array}$ & 1 & 3 & 8 & 11 & 5 & 2 & 5 & 7 & 0 & 0 & 3 & 4 & 4 & 3 & 1 & 1 \\
\hline $\begin{array}{l}\text { (III) Prior CLIL } \\
\text { training knowledge }\end{array}$ & 4 & 3 & 23 & 7 & 6 & 8 & 2 & 1 & 2 & 1 & 6 & 4 & 0 & 3 & 0 & 2 \\
\hline $\begin{array}{l}\text { (IV) Digital } \\
\text { competence }\end{array}$ & 0 & 0 & 2 & 5 & 12 & 1 & 0 & 4 & 3 & 0 & 1 & 2 & 0 & 2 & 0 & 0 \\
\hline $\begin{array}{l}\text { (V) Knowledge } \\
\text { in language } \\
\text { acquisition }\end{array}$ & 3 & 9 & 7 & 0 & 1 & 0 & 3 & 0 & 0 & 0 & 0 & 0 & 0 & 1 & 1 & 0 \\
\hline (VI) Motivation & 3 & 9 & 1 & 1 & 3 & 1 & 2 & 1 & 0 & 1 & 0 & 1 & 1 & 0 & 0 & 0 \\
\hline (VII) Teachers' time & 0 & 0 & 0 & 1 & 2 & 3 & 0 & 7 & 0 & 0 & 1 & 0 & 0 & 1 & 0 & 0 \\
\hline $\begin{array}{c}\text { (VIII) CLIL specific } \\
\text { materials }\end{array}$ & 1 & 1 & 4 & 4 & 6 & 3 & 0 & 5 & 1 & 0 & 2 & 2 & 5 & 7 & 0 & 0 \\
\hline $\begin{array}{l}\text { (IX) Support/ } \\
\text { cooperation }\end{array}$ & 0 & 0 & 7 & 1 & 2 & 6 & 0 & 13 & 0 & 1 & 7 & 2 & 1 & 2 & 0 & 0 \\
\hline $\begin{array}{l}\text { (X) Pedagogical } \\
\text { preparation }\end{array}$ & 1 & 2 & 3 & 25 & 7 & 2 & 2 & 5 & 4 & 0 & 1 & 4 & 3 & 4 & 1 & 1 \\
\hline $\begin{array}{l}\text { (XI) Language } \\
\text { awareness }\end{array}$ & 1 & 4 & 1 & 4 & 0 & 0 & 4 & 1 & 0 & 0 & 0 & 0 & 0 & 0 & 0 & 1 \\
\hline
\end{tabular}

It is to underline that the same suggestion could be given by the authors for more than one lack at the same time, which determine the differences between the number of occurrences per lack and what is reported in the table.

These results firstly show the main focus of attention by the authors and stakeholders on filling the Pedagogical-Educational, as well as the specific CuIL preparation lacks through further training. Secondly, FL updating and Collaborative practices are seen as important, both as lacks and as suggestions, but not as the training on generically educational and specifically CLIL strategies. It also appears that the lack of motivation could be solved by further competence in FL acquisition. 
Finally, the common feeling among cliL teachers of not having enough time, both in general and to manage CLIL specific materials, are not pointed out here as relevant.

As far as pre-service is concerned, the results are reported below:

TABLE 4

Relations between pre-service lacks and suggestions/good practices in terms of occurrences (stressed in grey the highest value)

\begin{tabular}{|c|c|c|c|c|c|c|c|c|}
\hline & 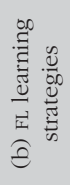 & 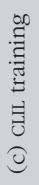 & 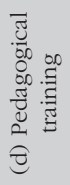 & 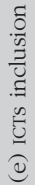 & 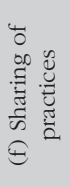 & 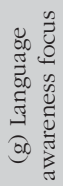 & 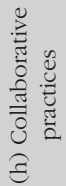 & 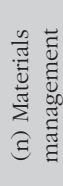 \\
\hline (I) Foreign language competence & 0 & 2 & 0 & 0 & 0 & 1 & 1 & 0 \\
\hline (II) Instructional problems & 0 & 2 & 1 & 2 & 1 & 1 & 1 & 1 \\
\hline (IV) Digital competence & 0 & 0 & 2 & 2 & 1 & 0 & 1 & 0 \\
\hline (V) Knowledge in language acquisition & 1 & 0 & 0 & 0 & 0 & 1 & 0 & 0 \\
\hline (X) Pedagogical preparation & 0 & 0 & 6 & 2 & 1 & 0 & 1 & 0 \\
\hline
\end{tabular}

The paucity of occurrences does not allow for considering these pre-service results as significant, but emphasis is placed on the importance of pedagogical training and it is given a different answer from in-service to lack II (Instructional/ planning problems).

For in-service teachers it is first suggested Pedagogical preparation, then CLIL training and Collaborative practices, to fill it; for pre-service ones CLIL training and ICTS are mainly cited.

\section{DisCUSSION AND CONCLUSIONS}

The aim of the present paper is to examine and analyse qualitative European data about the implementation of the clil teachers' training, in order to highlight lacks and provide suggestions to improve it.

It clearly emerges that it is not yet considered highly important to provide CLIL training to pre-service teachers at University, in order to certify their methodological competences, apart from in Spain. This is a relevant point, because this approach concerns many educational aspects to acquire (see 4.1), which are perceived as the main lacks when the preparation for CLIL happens later (in order of importance: Prior CLIL training, experience or knowledge; Pedagogical/educational preparation, as in integration; and Instructional/planning problems).

The big effort to train teachers in FLs and Linguistics make them perceive this field not as defective as others, at least among teachers with a certain experience 
MARIA ELISABETTA PORCEDDA Y JUAN GONZÁLEZ-MARTÍNEZ

with CLIL (Pérez Cañado, 2018b): we can so affirm that the way to multilingualism is focused within cLIL trainers and researchers, such as the low percentage of references for lack of language awareness could indicate. But are teachers aware of the importance of language awareness, so as to promote it through CLIL? The European Union highlights it as a point to improve (Council of the European Union, 2019), so it would be better to take it into account in any case within CLIL teacher training.

The last here resulting fields of training (ICTs and online tools, Pedagogy for CLIL, Evaluation and Materials' development) are essential for proper cLIL implementation and in particular to finally achieve a major change in teaching, expressly required by the European Directives, starting from the White Paper (European Commission, 1995). Indeed, pedagogical preparation and the instructional/planning issue (including evaluation and materials' development) result as the second and third lacks perceived. It might be so crucial, in training cLIL teachers, starting to consider essential their adequate pedagogical competence, definitely student-centered and not only rearranged through what they know, but putting as first the evaluation of students' pathways to the achievement of skills and competences for their life. This necessarily implies deep collaboration in their classrooms among all the participants to the students' education, as a community of teaching and learning, which is founded on common Learning by doing, in which ICTs should be massively present, due to their strong involvement in the learning reality especially of students. And the reason why the above four resulting fields of training are the last is to deeply further investigate, given that their importance for schooling, not only in CLIL training.

Prior CLIL training, experience or knowledge is the first lack for importance, though any CLIL teacher has previously attended specific methodological courses. It highlights the needs for continuous updating, both of methods and linguistically, and of environments, mainly online of teachers' communities, for sharing experiences and good practices, as this research shows. It also emerges that the collaborative approach is seen as highly relevant for ClIL training and, summing its percentual with the sharing of practices, which can be another way to collaborate, it is perceived as the second macro-suggestion ( 79 occurrences, including $\mathrm{f}$ and $\mathrm{h}$ ), after the linguistic one (87 occurrences, including a, b, g, o). Particularly, telecollaboration is seen as an engaging way both for training and for sharing experiences among teachers, because it fosters especially the competencies of Learning by Doing and Lifelong Learning and it can be useful to improve planning and instructional needs. It recalls the Transformative Pedagogy, experience-based and aiming at a higher reflection of practices (Infante, Benvenuto and Lastrucci, 2009), which should be further researched in this field.

Surprisingly, mobilities are scarcely adopted, though the support of European projects such as Erasmus+, but they could be an effective path for teachers to achieve the multilingualism and create personal networks for CLIL collaborative environments. In Spain there are micro-sharing environments created through successful in-house cLIL training at school: it provides for Spanish before-trained 
teachers as trainers of colleagues and with the support of associations of teachers, which promote cross-curricular teaching (Fernández Costales and Lahuerta Martínez, 2014). Undoubtedly, the CLIL approach demands collaborative practices and requires support from educational authorities and collaboration among teachers, which is perceived as another aspect to improve; but it is also to highlight that its implementation, if it is not a lip-service, thanks to this multi-collaboration (Pérez Cañado, 2018a), almost withdraws the lacks of motivation and of time for teachers. The latter is determined especially by having to accurately plan the interventions (objectives, strategies, FL level, materials and tools, tasks, and rubrics to evaluate). And the same collaborative practices, with the use of ICTs, are seen as answers to the lack of CLIL specific materials, after a specific training.

Regarding ICTS, it is finally to underline another result: although the management of them is not perceived as a relevant lack, the inclusion of ICTs and online tools is included as a suggestion for any lack, apart from specifically the FL competence and the pedagogical preparation. Does the main and in-presence University training in these fields influence this result? Or do teachers consider them as a prerogative of theoretical experts? It could be opportune answering these questions, at the moment open and to be verified in the field. But it might be too that they are felt as strong lacks due to not being improved by collaborative practices and information on Clil research (Pérez Cañado, 2018b), in particular about pedagogical strategies. Nevertheless, the CLIL approach takes so many advantages from ICTs that important worldwide experiences of online teacher training have been successfully provided from Italy by EVO-TESOL (Cinganotto, 2016); by eTwinning and INDIRE, always international and from Italy for a Learning Event (Cinganotto, 2017); through an Erasmus+ project of telecollaboration involving Belgium, France, Germany, the Netherlands, Spain, and UK (Jauregi and Melchor-Couto, 2017); as e-learning at 'Orientale' University for their trainees in Italy, through blended courses (De Santo and De Meo, 2016); and in Spain, through online CLIL courses (Carrió-Pastor and Forteza, 2019) and telecollaboration (Bueno-Alastuey, Villarreal and García-Esteban, 2018; García-Esteban, Villarreal and Bueno-Alastuey, 2019).

To conclude, it results that CliL teachers training shows in all of Europe, on the one hand, precise lacks, but, on the other, many good practices and suggestions to be widespread and implemented. Indeed, the stakeholders, especially teachers, as well as researchers are highly concerned with the improvement of this approach, especially soliciting collaborative practices and sharing of experiences, in particular through online communities. Besides, pre-service training should clearly to be increased at University, so as to prevent instructional lacks above all, but also to found teachers' experiential Lifelong learning.

We hope for continued and deeper cooperation among cLIL researchers and teachers, in order to consider their results as the basis of cutting-edge schooling, according to EU policy. 
MARIA ELISABETTA PORCEDDA Y JUAN GONZÁLEZ-MARTÍNEZ

\section{REFERENCES}

Aiello, J.; Di Martino, E. \& Di Sabato, B. (2017). Preparing teachers in Italy for CLIL: reflections on assessment, language proficiency and willingness to communicate. International Journal of Bilingual Education and Bilingualism, 20(1), 69-83.

Alcaraz-Mármol, G. (2018). Trained and Non-Trained Language Teachers on CLIL Methodology: Teachers' Facts and Opinions about the CLIL Approach in the Primary Education Context in Spain. Latin American Journal of Content and Language Integrated Learning, 11(1), 39-64.

Ball, P.; Kelly, K. \& Clegg, J. (2015). Putting CuIL into Practice. Oxford: Oxford University Press. (pp. 52-61).

Biçaku, R. Ç. (2011). CLIL and teacher training. Procedia-Social and Behavioural Sciences, $15,3821-3825$.

Bueno-Alastuey, M. C.; Villarreal, I. \& García Esteban, S. (2018). Can telecollaboration contribute to the TPACK development of pre-service teachers? Technology, Pedagogy and Education, 5139(May), 1-14.

Campillo, J. M.; Sánchez, R.; \& Miralles, P. (2019). Primary Teachers' Perceptions of CLIL Implementation in Spain. English Language Teaching, 12(4), 149-156.

Carrió-Pastor, M. L.; \& Forteza, F. R. (2019). La planificación temporal y la evaluación en la formación online de futuros docentes en el AICLE. Time planning and evaluation in online pre-service teacher training in CLIL. Tejuelo, 30, 111-150.

Cenoz, J. (2013). Discussion: Towards an educational perspective in CLIL language policy and pedagogical practice. International Journal of Bilingual Education and Bilingualism, 16(3), 389-394.

Chaieberras, Z.; \& Rascón-Moreno, D. (2018). Perspectives of Compulsory Secondary Education Students on Bilingual Sections in Madrid (Spain). English Language Teaching, 11(10), 152-161.

Cinganotto, L. (2016). Teacher training - Content and Language Integrated Learning with Technologies: a global online training experience. The EuROCAll Review, 24(2), 56-64.

Cinganotto, L. (2017). Experiential learning for teacher training: A case example on language, content and technologies in a learning event by eTwinning. Journal of E-Learning and Knowledge Society, 13(1), 91-111.

Coonan, C. M. (2011). ClIL in Language Teacher Training. Studi Di Glottodidattica, 2(1), 1-14.

Council of the European Union (2019). Council Recommendation of 22 May 2019 on a Comprehensive Approach to the Teaching and Learning of Languages. Official Journal of the European Union, C 189(2017), 15-22.

Coyle, D. (1999). Theory and planning for effective classrooms: supporting students in content and language integrated contexts. In J. Masih (Ed.), Learning through a Foreign Language (pp. 42-62). London: CILT.

Coyle, D. (2013). Listening to learners: An investigation into "successful learning» across CLIL contexts. International Journal of Bilingual Education and Bilingualism, 16(3), 244-266.

Czura, A. \& Papaja, K. (2013). Curricular models of cliL education in Poland. International Journal of Bilingual Education and Bilingualism, 16(3), 321-333.

Dalton-Puffer, C. (2011). Content-and-language integrated learning: From practice to principles? Annual Review of Applied Linguistics, 31, 182-204.

De Santo, M. \& De Meo, A. (2016). E-training for the CLIL in a moodle-based community of learning. Journal of E-Learning and Knowledge Society, 12(3), 41-49. 
Durán-Martínez, R. \& Beltrán-Llavador, F. (2016). A Regional Assessment of Bilingual Programmes in Primary and Secondary Schools: the Teachers' Views. Porta Linguarum, 25, 79-92.

European Commission (1995). White paper on education and learning - Teaching and learning: towards the learning society. European Commission. 70.

European Commission Note (2019). Interventions proposal for a council recommendation on a comprehensive approach to the teaching and learning of languages. European Journal of Language Policy, 11(1), 129-137.

European Council (2008). Council resolution of 21 November 2008 on a European strategy for multilingualism. Official Journal of the European Union, C320. 2008/C 3210/01.

Favilli, F.; Maffei, L. \& Peroni, R. (2013). Teaching and Learning Mathematics in a Non-Native Language: Introduction of the CLIL Methodology in Italy. US-China Education Review A, 3(6), 374-380.

Fernández Costales, A. \& Lahuerta Martínez, A. C. (2014). New Approaches in English Language Teaching: Teacher Training in the Framework of Content and Language Integrated Learning. Magister, 26(1), 18-24.

García-Esteban, S.; Villarreal, I. \& Bueno-Alastuey, M. C. (2019). The effect of telecollaboration in the development of the Learning to Learn competence in CLIL teacher training. Interactive Learning Environments, 0(0), 1-14.

Gierlinger, E. (2015). "You can speak German, sir': on the complexity of teachers» L1 use in CLIL. Language and Education, 29(4), 347-368.

González Davies, M. (2016). Children's literature and plurilingualism in a teacher training programme. A CLIL approach focusing on Didactics (FOD). EDETANIA, 49, 91-105.

González-Martínez, J.; Serrat-Sellabona, E.; Estebanell-Minguell, M.; Rostan-Sánchez, C. \& Esteban-Guitart, M. (2018). Sobre el concepto de alfabetización transmedia en el ámbito educativo. Una revisión de la literatura. Comunicación y Sociedad, 33, 15-40.

Gutiérrez Almarza, G.; Durán Martínez, R. \& Beltrán Llavador, F. (2012). CLIL in teacher training: A Nottingham Trent University and University of Salamanca experience. Encuentro, 21, 48-62.

Hodaňová, J. \& Laitochová, J. (2015). Phenomenon of Excellence at Future Teachers Training. Procedia - Social and Behavioural Sciences, 174, 3750-3756.

Infante, D.; Benvenuto, G. \& Lastrucci, E. (2009), The effects of CLIL from the perspective of experienced teachers. In D. Marsh, P. Mehisto, D. Wolff, R. Aliaga,T. Asikanen \& M. J. Frigols-Martin (Eds.). ClIL Practice: Perspectives from the Field (pp. 156-163). Jyväskylä:CCN: University of Jyväskylä.

Jauregi, K. \& Melchor-Couto, S. (2017). The TeCoLa project: pedagogical differentiation through telecollaboration and gaming for intercultural and content integrated language teaching. The EUROCALL Review, 2017, 163-169.

Jerez Montoya, T. (2016). In-Service Teacher Perception of Iwb Usage and Training in Technology-Enhanced Clil Classrooms. Encuentro, 25, 13-26.

Lancaster, N. K. (2016). Stakeholder Perspectives on CLIL in a Monolingual Context. English Language Teaching, 9(2), 148.

Lucietto, S. \& Rasom, O. (2011). Consultancy work in an innovative plurilingual CLIL programme. Context, relationships and evaluation. Procedia - Social and Behavioural Sciences, 30, 1438-1446.

Marsh, D. (2002). The European Dimension: Actions, Trends and Foresight Potential. Strasbourg: European Commission. Unicom, University of Jyvaskyla. 
MARIA ELISABETTA PORCEDDA Y JUAN GONZÁLEZ-MARTÍNEZ

CLIL TEACHER TRAINING: LACKS AND SUGGESTIONS FROM A SYSTEMATIC LITERATURE REVIEW

Marsh, D. \& Frigols Martín, M. J. (2012). Content and Language Integrated Learning. Introduction in C. A. Chapelle. The Encyclopedia of Applied Linguistics. Chichester, West Sussex, UK.

Marsh, D.; Mehisto, P.; Wolff, D. \& Frígols-Martín, M. J. (2012). European Framework for CLIL Teacher Education. A framework for the professional development of CLIL teachers. Encuentro, 21, 39.

Martí, O. \& Portolés, L. (2019). Spokes in the Wheels of cLIL for Multilingualism or How Monolingual Ideologies Limit Teacher Training. English Language Teaching, 12(2), 17.

Martín del Pozo, M. Á. (2017). Training Teachers for English Medium Instruction: Lessons from Research on Second Language Listening Comprehension. Revista de Lingüistica y Lenguas Aplicadas, 12, 55-63.

Melara Gutiérrez, J. \& González López, I. (2016). Trazos para el diseño del perfil competencial de la figura del maestro bilingüe. Revista Española de Pedagogía, 74(264), 357-380.

Meyer, O. (2010). Towards quality-CLIL: successful planning and teaching strategies. Pulso, 33(1), 11-29.

Milla Lara, M. D. \& Casas Pedrosa, A. V. (2018). Teacher Perspectives on CLIL Implementation: A Within-Group Comparison of Key Variables. Porta Linguarum, 29, 159-180.

Moore, E. \& Dooly, M. (2010). «How do the apples reproduce (Themselves)?» How teacher trainees negotiate language, content, and membership in a cLIL science education classroom at a Multilingual University. Journal of Language, Identity and Education, 9(1), 58-79.

Nightingale, R. \& Safont, P. (2019). Conversational Style and Early Academic Language Skills in CLIL and Non-ClIL Settings: A Multilingual Sociopragmatic Perspective. English Language Teaching, 12(2), 37.

O'Dowd, R. (2018). The training and accreditation of teachers for English medium instruction: an overview of practice in European universities. International Journal of Bilingual Education and Bilingualism, 21(5), 553-563.

Oattes, H.; Oostdam, R.; de Graaff, R. \& Wilschut, A. (2018). The challenge of balancing content and language: Perceptions of Dutch bilingual education history teachers. Teaching and Teacher Education, 70, 165-174.

Okoli, C. \& Schabram, K. (2010). A Guide to Conducting a Systematic Literature Review of Information Systems Research. Working Papers on Information Systems, 10(26), 1-51.

Pérez Cañado, M. L. (2016a). Are teachers ready for CLIL? Evidence from a European study. European Journal of Teacher Education, 39(2), 202-221.

Pérez Cañado, M. L. (2016b). Teacher training needs for bilingual education: in-service teacher perceptions. International Journal of Bilingual Education and Bilingualism, 19(3), 266-295.

Pérez Cañado, M. L. (2018a). CLIL and pedagogical innovation: Fact or fiction? International Journal of Applied Linguistics, 28(3), 1-22.

Pérez Cañado, M. L. (2018b). Innovations and Challenges in CLIL Implementation in Europe. Theory into Practice, 57(3), 212-221.

Pokrivcakova, S. (2015). CLIL in Slovakia: projects, research, and teacher training (20052015). In CLIL in Foreign Language Education (pp. 17-29). Nitra, Slovakia: Constantine the Philosopher University. Art.

Rea Rizzo, C. \& Carbajosa Palmero, N. (2014). CLIL Teacher training at the UPCT: present and future within the EHEA. REDU Revista de Docencia Universitaria, 12(4), 377-393. 
68 MARIA ELISABETTA PORCEDDA Y JUAN GONZÁLEZ-MARTÍNEZ CLIL TEACHER TRAINING: LACKS AND SUGGESTIONS FROM A SYSTEMATIC LITERATURE REVIEW

Reitbauer, M.; Fürstenberg, U.; Kletzenbauer, P. \& Marko, K. (2018). Towards a Cognitive-Linguistic Turn in CLIL: Unfolding Integration. Latin American Journal of Content and Language Integrated Learning, 11(2018), 87-107.

San Isidro, X. \& Lasagabaster, D. (2019). Monitoring of Teachers' Views on Both CLIL and the Development of Pluriliteracies: A Longitudinal Qualitative Study. English Language Teaching, 12(2), 1-16.

Trentinné-Benkő, É. (2016). Ten Years of CLIL Teacher Training at ELTE TóK. In T. J. Karlovitz (Ed.) Studies from Education and Society (pp. 142-152).

Van Kampen, E.; Admiraal, W. \& Berry, A. (2016). Content and language integrated learning in the Netherlands: teachers self-reported pedagogical practices. International Journal of Bilingual Education and Bilingualism, 0(0), 1-15. 